\title{
Evaluation of Struvite Recovered from Swine Wastewater as an Alternative Phosphorus Source in Broiler Feed
}

\author{
Mijung Kim ${ }^{1,+}$, Soomin Shim ${ }^{1,+}{ }^{\text {, Arif Reza }}{ }^{1,2,+} \oplus$, Seungsoo Kim ${ }^{1}$, Seunggun Won ${ }^{3}$, \\ Baedong Jung ${ }^{4}$, Jinsoo $\mathrm{Kim}^{1}$ and Changsix Ra ${ }^{1, * \mathbb{D}}$ \\ 1 Department of Animal Industry Convergence, College of Animal Life Sciences, Kangwon National \\ University, Chuncheon 24341, Korea; sesang000@gmail.com (M.K.); vibrato7@naver.com (S.S.); \\ reza.arif@kangwon.ac.kr (A.R.); seung_su89@nate.com (S.K.); kjs896@kangwon.ac.kr (J.K.) \\ 2 Department of Environmental Science, College of Agricultural Sciences, IUBAT-International University of \\ Business Agriculture and Technology, Dhaka 1230, Bangladesh \\ 3 Department of Animal Resources, College of Life and Environmental Science, Daegu University, \\ Gyeongsan 38453, Korea; swon@daegu.ac.kr \\ 4 Department of Veterinary Science, Kangwon National University, Chuncheon 24341, Korea; \\ bdjung@kangwon.ac.kr \\ * Correspondence: changsix@kangwon.ac.kr; Tel.: +82-33-250-8618 \\ + These authors contributed equally to this work.
}

Received: 28 August 2019; Accepted: 10 October 2019; Published: 11 October 2019

\begin{abstract}
The objective of this study was to evaluate the feasibility of reutilizing phosphorus (P) recovered as struvite from swine wastewater as an alternative to commercial P sources in broiler feed. The recovered struvite was pre-treated as microwave irradiated struvite (MS) and incinerated struvite (IS) to reduce the $\mathrm{NH}_{4}-\mathrm{N}$ concentration in recovered struvite before application. A preliminary study on the growth performance and blood metabolites of broiler chickens was then performed to assess the effect of MS and IS by comparing with commercial monobasic dicalcium phosphate (MDCP, control). A total of 204 male Ross 308 broiler chickens (mean body weight (BW) of $80 \pm 5 \mathrm{~g}$ ) were randomly allotted to each of 12 pens. The growth performance and blood metabolites analysis of broiler chickens showed no significant difference among the test materials $(p>0.05)$. However, the apparent total tract digestibility of crude fat was significantly higher in MS and IS treated groups compared to the control $(p<0.05)$. The digestibility of crude ash in control was significantly lower than that in MS $(p<0.05)$. The results suggested that $P$ recovered from swine wastewater as struvite can be reutilized as an alternative $P$ source in broiler feed without adverse effects on growth performance and blood metabolites through proper pre-treatment. To our knowledge, this is the first study to evaluate the potential of using struvite in animal feed. This study provides primary evidence for the safety and efficacy of using pre-treated struvite as an alternative source of $\mathrm{P}$ in animal feed and will encourage further studies with more rigorous design.
\end{abstract}

Keywords: struvite; swine wastewater; microwave irradiation; incineration; broiler feed

\section{Introduction}

Phosphorus $(\mathrm{P})$ is a non-renewable and non-replaceable element for animal and plant growth. There is no substitution of $\mathrm{P}$ as a fertilizer and feed additive in agricultural production systems, and therefore, ensuring a substantial amount of $\mathrm{P}$ will be necessary for future food security [1-3]. Most of the $\mathrm{P}$ used in livestock feed and applied as fertilizers are either lost in wastewater or by leaching and runoff $[4,5]$. P concentration in livestock wastewater is generally high (600 to $1400 \mathrm{mg} / \mathrm{L})[6]$ and therefore 
P recovery from livestock wastewater seems necessary. Up until now, different physico-chemical methods have been introduced to recover P from livestock wastewater [7]. Among those methods, struvite precipitation has been widely studied. The recovery of struvite from wastewater would be economically more beneficial than using typical chemical reagents for wastewater treatment [8].

The animals' dietary $\mathrm{P}$ requirements have been calculated based on total $\mathrm{P}$ concentration in the feed. Due to low nutrient use efficiency by the animal, swine wastewater contains nutrients and organic materials at high concentrations [9]. In general, around $75 \%$ of the $\mathrm{P}$ in feed cannot be digested by the swine $[10,11]$. There is general speculation that $\mathrm{P}$ in the animal feed is absorbed in the intestine after feeding and therefore P present in the struvite recovered from swine wastewater cannot be redigested by the animals. The majority $(60 \%$ to $70 \%)$ of the total $\mathrm{P}$ present in swine wastewater is organic P [12], while only inorganic $\mathrm{P}$ (in monophosphate form) is involved during the struvite crystallization process. Commercial $\mathrm{P}$ sources like monocalcium phosphate (MCP) and monobasic dicalcium phosphate (MDCP) are also monophosphates. Therefore, $\mathrm{P}$ in struvite is expected to be similarly soluble. Moreover, as struvite is highly soluble at low $\mathrm{pH}, \mathrm{P}$ in struvite can be easily solubilized and absorbed in the stomach and intestine. In addition, the P recovered from swine wastewater as struvite includes relatively less toxic heavy metals when compared to municipal and chemical or electronic industries, which means that the feasibility of $P$ recycle increases without consideration of further heavy metal removal $[13,14]$.

In Korea, livestock wastewater is treated in centralized wastewater treatment plants $[15,16]$. Therefore, installing the P recovery process in centralized livestock wastewater treatment plants could be sustainable and economical, as well as protecting the environment and actuate P circular economy. Until now, the struvite recovered from livestock waste sources has only been utilized as an alternative phosphate fertilizer [17]. However, the struvite application may be expanded to the other fields, such as animal feed and chemical industries $[18,19]$, if the recovered $P$ in the form of struvite is biologically safe. The biggest obstacle in $\mathrm{P}$ purification methods is attributed to the unbalanced nitrogen $(\mathrm{N})$ and $\mathrm{P}$ ratio, where the concentration of $\mathrm{NH}_{4}-\mathrm{N}$ is considerably higher than $\mathrm{PO}_{4}-\mathrm{P}$ [20]. $\mathrm{NH}_{4}-\mathrm{N}$ is highly toxic to animals and its accumulation in the intracellular sites can cause severe damage. It is therefore necessary to pre-treat the recovered struvite before its use as an alternative $\mathrm{P}$ source in broiler feed. Reza et al. reported that among the pre-treatment methods, the microwave irradiation is cost-effective and less time-consuming and can reduce the $\mathrm{NH}_{4}-\mathrm{N}$ concentration by about $24.9 \%$ in recovered struvite [13]. On the other hand, incineration is a conventional and widely accepted method of pre-treatment. Our previous study on the growth performance of Carp (Cyprinus carpio) using struvite as an alternative dietary source of $\mathrm{P}$ was successful and showed no significant difference in weight gain, feed conversion ratio, protein efficiency ratio, and specific growth rate, with some improvements (1.4\% to $2.8 \%$ ) compared to MCP [18].

Therefore, the hypothesis of this study was that $\mathrm{P}$ recovered from swine wastewater as struvite may be a similarly effective, soluble, and sustainable alternative to commercial $\mathrm{P}$ sources as a feed additive. To check the hypothesis, some initial experiments were conducted to study the feasibility of struvite application as an alternative P source in broiler feed. It should be noted that this preliminary study was intended to evaluate the possibility of reutilizing struvite in animal feed by performing some initial experiments.

\section{Materials and Methods}

\subsection{P Recovery Process and Pre-Treatment}

The $\mathrm{P}$ recovery process and pre-treatment methods used in this study were described in detail in our earlier studies [13,21]. To find cost-effective treatments for the removal of $\mathrm{NH}_{4}-\mathrm{N}$ from the recovered struvite, microwave irradiation $\left(80 \mathrm{~Hz} / \mathrm{g}\right.$ for $5 \mathrm{~min}$ ) and incineration $\left(550{ }^{\circ} \mathrm{C}\right.$ for $\left.30 \mathrm{~min}\right)$ treatments were applied. The recovered and pre-treated materials were characterized by X-ray diffraction (XRD) (PANalytical X'Pert-PRO MPD, Malvern Panalytical BV, Almelo, The Netherlands). 


\subsection{Growth Performance Test in Broiler}

A growth trial was conducted with pretreated struvite (microwave irradiated struvite, MS; incinerated struvite, IS) as an alternative to commercial P sources to study the effect of MS and IS on the growth performance and blood parameters of broiler chickens. The protocol for the experiment was approved and broiler chickens were cared for according to the guidelines of the Institutional Animal Care and Use Committee of Kangwon National University, Chuncheon, Republic of Korea (IACUC \# KW 130620-1).

For three treatment groups, including control (four replicates/group), a total of 204 male broiler chickens (Ross 308; mean body weight (BW) $80 \pm 5 \mathrm{~g}$ ) were allotted to each of 12 pens (17 broilers/pen) and the floor of the pens was covered with rice hull. The test materials (MS, IS, and commercial monobasic dicalcium phosphate (MDCP, control)) were added to an isocaloric and isonitrogenous corn-soybean-based diets (Table 1) in two phases as starter (1-14 days) and finisher (15-28 days). Individual BW and feed intake of each replicate were recorded weekly to calculate BW gain and feed conversion ratio (FCR). Apparent total tract digestibility (ATTD) of the test materials was analyzed in the fourth week of the experimental feeding using excreta samples of four randomly selected broilers from each pan after allocation to individual cages.

Table 1. Ingredients and proximate composition of the experimental diets for broilers (as-fed basis).

\begin{tabular}{|c|c|c|c|c|c|c|}
\hline \multirow[t]{2}{*}{ Items } & \multicolumn{2}{|c|}{$\operatorname{MDCP}^{1}$} & \multicolumn{2}{|c|}{$\mathrm{MS}^{2}$} & \multicolumn{2}{|c|}{ IS $^{3}$} \\
\hline & $\begin{array}{c}\text { Starter } \\
\text { (1-14 days) }\end{array}$ & $\begin{array}{c}\text { Finisher } \\
\text { (15-28 days) }\end{array}$ & $\begin{array}{c}\text { Starter } \\
\text { (1-14 days) }\end{array}$ & $\begin{array}{c}\text { Finisher } \\
\text { (15-28 days) }\end{array}$ & $\begin{array}{c}\text { Starter } \\
\text { (1-14 days) }\end{array}$ & $\begin{array}{c}\text { Finisher } \\
\text { (15-28 days) }\end{array}$ \\
\hline \multicolumn{7}{|c|}{ Ingredients (\%) } \\
\hline Corn & 39.29 & 39.54 & 39.29 & 39.54 & 39.29 & 39.54 \\
\hline Wheat & 15.00 & 17.00 & 15.00 & 17.00 & 15.00 & 17.00 \\
\hline Gluten & 2.00 & 1.52 & 2.00 & 1.52 & 2.00 & 1.52 \\
\hline DDGS $^{4}$ & 4.00 & 4.00 & 4.00 & 4.00 & 4.00 & 4.00 \\
\hline Whole soybean & 8.00 & 9.00 & 8.00 & 9.00 & 8.00 & 9.00 \\
\hline Soybean meal & 20.56 & 17.92 & 20.56 & 17.92 & 20.56 & 17.92 \\
\hline Rapeseed meal & 2.00 & 2.00 & 2.00 & 2.00 & 2.00 & 2.00 \\
\hline Limestone & 1.52 & 1.49 & 1.58 & 1.72 & 1.80 & 1.72 \\
\hline MDCP & 1.08 & 0.88 & - & - & - & - \\
\hline MS & - & - & 1.02 & 0.83 & - & - \\
\hline IS & - & - & - & - & 0.87 & 0.71 \\
\hline Salt & 0.33 & 0.33 & 0.10 & 0.15 & 0.26 & 0.27 \\
\hline Beef tallow & 4.52 & 4.76 & 4.52 & 4.76 & 4.52 & 4.76 \\
\hline Choline chloride & 0.16 & 0.19 & 0.16 & 0.19 & 0.16 & 0.19 \\
\hline DL-Methionine & 0.31 & 0.29 & 0.31 & 0.29 & 0.31 & 0.29 \\
\hline L-lysine & 0.68 & 0.58 & 0.68 & 0.58 & 0.68 & 0.58 \\
\hline Threonine & 0.1 & 0.05 & 0.10 & 0.05 & 0.10 & 0.05 \\
\hline Vitamin premix ${ }^{a}$ & 0.1 & 0.10 & 0.10 & 0.10 & 0.10 & 0.10 \\
\hline Mineral premix ${ }^{b}$ & 0.1 & 0.10 & 0.10 & 0.10 & 0.10 & 0.10 \\
\hline Clinacox & 0.05 & 0.00 & 0.05 & 0.00 & 0.05 & 0.00 \\
\hline Lactovita & 0.2 & 0.20 & 0.20 & 0.20 & 0.20 & 0.20 \\
\hline Maduramycin & 0.00 & 0.05 & 0.00 & 0.05 & 0.00 & 0.05 \\
\hline Total & 100.00 & 100.00 & 100.00 & 100.00 & 100.00 & 100.00 \\
\hline \multicolumn{7}{|c|}{ Composition (\%) } \\
\hline Dry matter & 89.58 & 89.82 & 89.58 & 89.82 & 89.58 & 89.82 \\
\hline $\mathrm{ME}^{5}(\mathrm{kcal} / \mathrm{kg})$ & 3150 & 3202 & 3150 & 3202 & 3150 & 3202 \\
\hline Crude protein & 21.00 & 20.00 & 21.00 & 20.00 & 21.00 & 20.00 \\
\hline Crude fat & 7.40 & 7.71 & 7.40 & 7.71 & 7.40 & 7.71 \\
\hline Calcium & 1.50 & 1.41 & 1.50 & 1.41 & 1.50 & 1.41 \\
\hline Phosphorus & 0.68 & 0.59 & 0.68 & 0.59 & 0.68 & 0.59 \\
\hline
\end{tabular}

${ }^{1} \mathrm{MDCP}$, monobasic dicalcium phosphate (Control group) ${ }^{2} \mathrm{MS}$, microwaved irradiated struvite; ${ }^{3}$ IS, incinerated struvite; ${ }^{4} \mathrm{DDGS}$, distiller's dried grain with solubles; ${ }^{5} \mathrm{ME}$, metabolism energy. ${ }^{\text {a }}$ Vitamin premix (per kg): Vit A, 14,000,000 IU; Vit D3, 3,000,000 IU; Vit E, 40,000 mg; Vit K3, 2400 mg; Vit B1, 1200 mg; Vit B2, 5000 mg; Vit B6, $3000 \mathrm{mg}$; Vit B12, $20 \mathrm{mg}$; Niacin, 40,000 mg; pantothene, $10,000 \mathrm{mg}$; folic acid, $500 \mathrm{mg}$; Biotin, $70 \mathrm{mg} .{ }^{\mathrm{b}}$ Mineral premix (per kg): Mn, 72,000 mg; Fe, 48,000 mg; Cu, 5000 mg; Zn, 60,000 mg; Se, 180 mg; Co, 240 mg; I, 1000 mg. 
For the analysis of internal organs, three broilers from each of the four pens in three treatment groups were randomly selected at the end of the experiment and euthanized using diethyl ether [22]. Each broiler was weighed and later slaughtered by cervical dislocation. Internal organs (heart, kidney, liver, gizzard, small intestine, cecum, and tibia) were extracted and relative organ weights (g/100 g BW) were calculated [23]. Lengths of small intestine and tibia were also measured. For bone content analysis (dry matter, crude ash, calcium (Ca), and P), tibia was freed of soft tissue and analyzed according to the standard procedure [24]. The blood tests were conducted at the end of the experimental feeding, i.e., after $24 \mathrm{~h}$ from the last dose of testing materials. Assay kits for the analysis of serum biochemicals were obtained from Chemon Inc., South Korea. Serum alanine aminotransferase (ALT), aspartate aminotransferase (AST), inorganic $\mathrm{P}, \mathrm{Ca}$, creatinine (CRE), and blood urea nitrogen (BUN) were determined using an automated blood biochemical analyzer (Model AU400, Olympus, Tokyo, Japan) and electrolyte analyzer (Model M744 ( $\mathrm{Na}+/ \mathrm{K}+/ \mathrm{Cl}-$ ) analyzer, Siemens, Deerfield, USA). For differential count, the blood sample of $1 \mathrm{~mL}$ was collected separately with anticoagulant and the differential leukocyte counts were made on monolayer blood films after being fixed and stained with Giemsa-Wright's stain [25]. Total leukocytes and red blood cell (RBC) count were determined using a haemocytometer.

\subsection{Statistical Analysis}

Differences in means among the treatments were analyzed with one-way ANOVA and multiple comparisons were performed using Tukey's HSD tests.

\section{Results}

\subsection{P Recovery as Struvite and Pre-Treatment}

During the recovery process, $\mathrm{P}$ was precipitated as dense fine particles in the reactor. The recovered material was then air-dried and characterized as struvite $\left(\mathrm{MgNH}_{4} \mathrm{PO}_{4} \cdot 6 \mathrm{H}_{2} \mathrm{O}\right)$ via XRD analysis with the nutrient contents of $5.5 \% \mathrm{NH}_{4}, 11.9 \% \mathrm{PO}_{4}$, and $10 \% \mathrm{Mg}$. The struvite was pre-treated using microwave irradiation and incineration to remove the $\mathrm{NH}_{4}-\mathrm{N}$ for further use in broiler feed. After pre-treatment, a change in nutrient concentration was observed. $\mathrm{Th}^{\mathrm{N}} \mathrm{NH}_{4}-\mathrm{N}$ concentration was decreased to $3.7 \%$, whereas $\mathrm{PO}_{4}$ and $\mathrm{Mg}$ concentrations remained almost the same (12.2\% and $9.8 \%$, respectively) after microwave irradiation treatment. In addition, microwave irradiation did not alter the chemical composition of the recovered struvite. Although the majority (about $67.3 \%$ ) of the pre-treated material was identified as $\mathrm{MgNH}_{4} \mathrm{PO}_{4} \cdot 6 \mathrm{H}_{2} \mathrm{O}$ by XRD analysis (Figure $1 \mathrm{~b}$ ), the microwave irradiation led to the formation of some other magnesium phosphates $\left(\mathrm{Mg}_{3}\left(\mathrm{PO}_{4}\right)_{2} \cdot \mathrm{XH}_{2} \mathrm{O}\right.$ ) (around 32.7\%). On the other hand, incineration at a high temperature $\left(550^{\circ} \mathrm{C}\right)$ denatured the recovered struvite to magnesium pyrophosphate $\left(\mathrm{Mg}_{2} \mathrm{P}_{2} \mathrm{O}_{7}\right)$ by eliminating ammonium and hydrates, which was confirmed by XRD analysis (Figure 1c). The $\mathrm{NH}_{4}-\mathrm{N}$ concentration was therefore reduced to $0.003 \%$ after incineration, while $\mathrm{PO}_{4}$ and $\mathrm{Mg}$ concentrations were increased to $18 \%$ and $11.5 \%$, respectively.

\subsection{Effect of Pre-Treated Struvites on Broiler}

No differences in feed intake, weight gain, and FCR were observed among treatment groups $(p>0.05)$ (Table 2). ATTD of the experimental diets showed no significant differences in dry matter and crude protein content of control, MS, and IS groups $(p>0.05)$ (Table 2). In the case of crude fat, the ATTD was significantly higher in MS and IS treated groups compared to control $(p<0.05)$. The digestibility of crude ash in control was comparable to IS but significantly lower than that in MS $(p<0.05)$. 
(a)

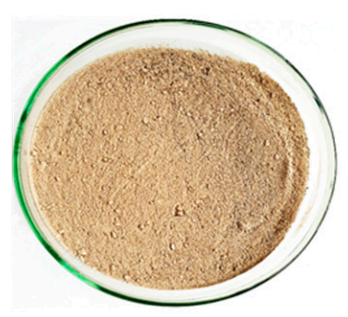

(b)

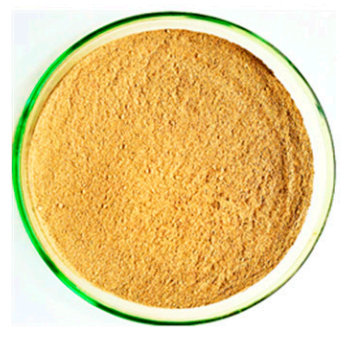

(c)

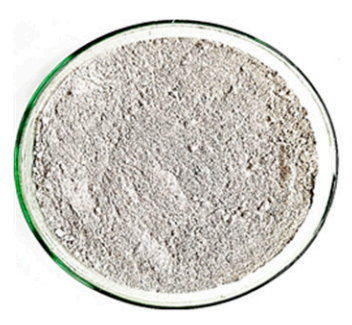

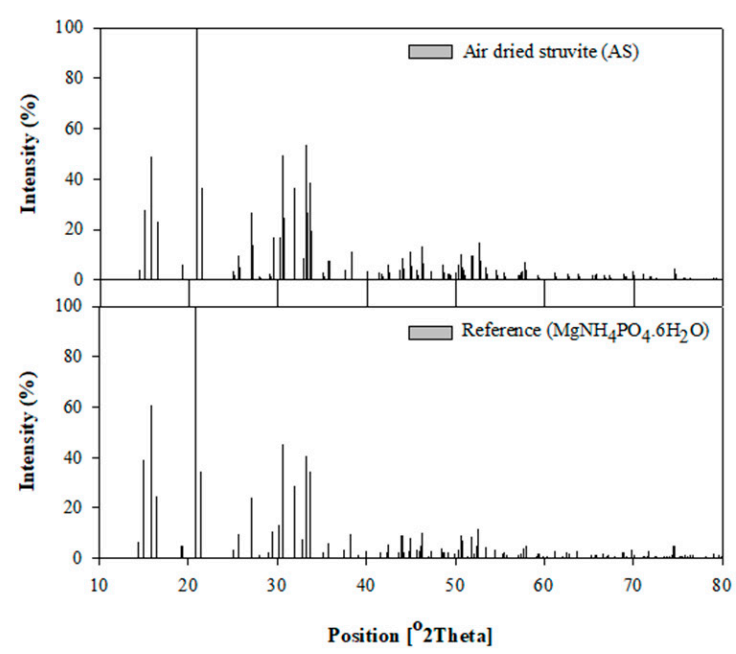
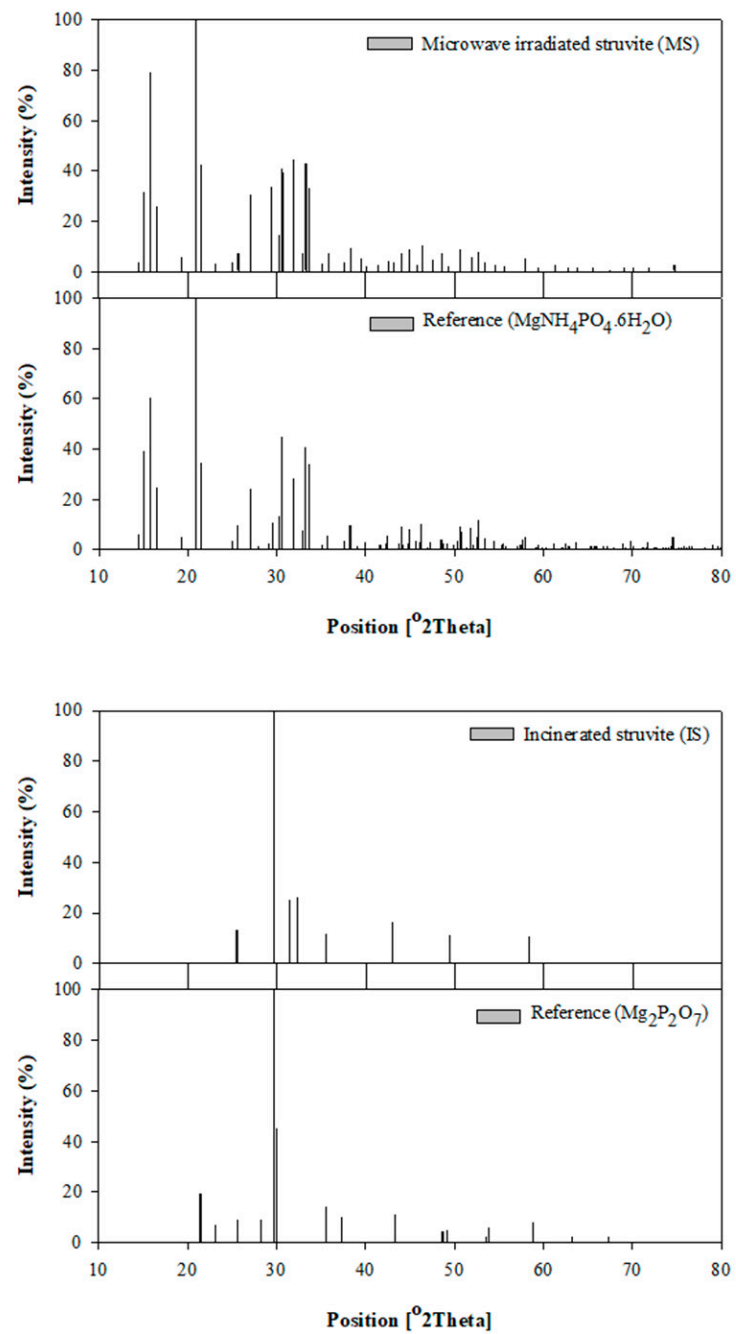

Figure 1. Pictures of recovered and pre-treated materials with the identification by XRD analyses. (a) air-dried struvite $\left(20^{\circ} \mathrm{C}\right.$ for 2 days $)$ (b) microwave irradiated struvite $(80 \mathrm{~Hz} / \mathrm{g}$ for $5 \mathrm{~min})$ (c) incinerated struvite $\left(550^{\circ} \mathrm{C}\right.$ for $\left.30 \mathrm{~min}\right)$.

Results of the relative weight of internal organs including heart, kidney, liver, gizzard, cecum, small intestine, and tibia extracted from broilers showed no significant differences among the test materials $(p>0.05)$ (Table 3). Similarly, the length of the small intestine and tibia also showed no 
difference in different treatment groups $(p>0.05)$. Analysis of ashed tibia for dry matter, crude ash, Ca, and $\mathrm{P}$ showed no significant differences among the control and treated groups $(p>0.05)$. No differences in blood parameters such as AST, ALT, BUN, CRE, inorganic P, RBC, white blood cells (WBC), neutrophils (NEU), lymphocytes (LYM), and eosinophils (EOS) were observed among treatment groups except Ca $(p>0.05)$ (Table 4$)$.

Table 2. Effect of test materials on body weight gain, feed intake, feed conversion ratio, and apparent total tract digestibility (\%) of nutrients of broilers.

\begin{tabular}{|c|c|c|c|c|c|}
\hline Items & MDCP & MS & IS & SEM $^{1}$ & $p$-Value \\
\hline \multicolumn{6}{|c|}{ Weight gain $(\mathrm{g} / \mathrm{bird})^{2}$} \\
\hline $1-14$ days & 634 & 646 & 630 & 11.56 & 0.88 \\
\hline 15-28 days & 1104 & 1123 & 1124 & 22.29 & 0.76 \\
\hline $1-28$ days & 1738 & 1769 & 1754 & 8.95 & 0.74 \\
\hline \multicolumn{6}{|c|}{ Feed intake $(\mathrm{g} / \mathrm{bird})^{3}$} \\
\hline 1-14 days & 1069 & 1049 & 1005 & 37.74 & 0.70 \\
\hline 15-28 days & 2176 & 2154 & 2221 & 64.94 & 0.57 \\
\hline 1-28 days & 3245 & 3203 & 3226 & 12.14 & 0.93 \\
\hline \multicolumn{6}{|c|}{ Feed conversion ratio (g of feed/of gain) ${ }^{4}$} \\
\hline $1-14$ days & 1.69 & 1.62 & 1.60 & 0.05 & 0.70 \\
\hline 15-28 days & 1.97 & 1.92 & 1.97 & 0.06 & 0.73 \\
\hline 1-28 days & 1.87 & 1.81 & 1.84 & 0.02 & 0.49 \\
\hline \multicolumn{6}{|c|}{ Apparent total tract digestibility $(\%)^{5}$} \\
\hline Dry matter & 71.41 & 72.20 & 72.63 & 0.48 & 0.61 \\
\hline Crude protein & 55.18 & 59.29 & 55.13 & 0.89 & 0.14 \\
\hline Crude fat & $81.47^{b}$ & $84.25^{\mathrm{a}}$ & $85.43^{a}$ & 0.56 & 0.00 \\
\hline Crude ash & $42.06^{b}$ & $50.29^{a}$ & $45.59^{a, b}$ & 1.46 & 0.05 \\
\hline
\end{tabular}

${ }^{1} \mathrm{SEM}$, standard error of the mean; ${ }^{\mathrm{a}, \mathrm{b}}$ Mean values within the same row with no common uppercase superscript indicate significant differences $(p<0.05) ;{ }^{2-4}$ Means represent four pens per treatment, 17 birds per pen; ${ }^{5}$ Means represent four cages per treatment, four birds per cage.

Table 3. Effect of test materials on organ weight and tibia composition (\%) of broilers (28 days).

\begin{tabular}{cccccc}
\hline Items & MDCP & MS & IS & SEM $^{\mathbf{1}}$ & $p$-Value \\
\hline \multicolumn{5}{c}{ Organ weight $(\mathrm{g} / 100 \mathrm{~g} \mathrm{BW})$} \\
\hline Heart & 0.76 & 0.77 & 0.67 & 0.02 & 0.41 \\
Kidney & 0.14 & 0.13 & 0.12 & 0.01 & 0.40 \\
Liver & 3.14 & 3.46 & 3.04 & 0.08 & 0.09 \\
Cecum & 0.55 & 0.66 & 0.65 & 0.03 & 0.19 \\
Gizzard & 1.37 & 1.36 & 1.34 & 0.02 & 0.85 \\
Small intestine & 4.73 & 4.57 & 4.58 & 0.13 & 0.90 \\
Tibia & 1.13 & 1.11 & 1.10 & 0.02 & 0.95 \\
\hline \multicolumn{7}{c}{ Length (cm) } \\
\hline Small intestine & 201.88 & 194.92 & 200.75 & 19.30 & 0.31 \\
Tibia & 11.43 & 11.19 & 11.20 & 0.62 & 0.23 \\
\hline \multicolumn{7}{c}{ Tibia composition } \\
\hline Dry matter & 49.44 & 48.16 & 48.56 & 0.26 & 0.10 \\
Crude ash & 54.09 & 51.29 & 51.07 & 0.66 & 0.10 \\
Calcium & 16.79 & 16.27 & 16.44 & 0.15 & 0.38 \\
Phosphorus & 8.46 & 8.10 & 8.24 & 0.08 & 0.23 \\
\hline
\end{tabular}

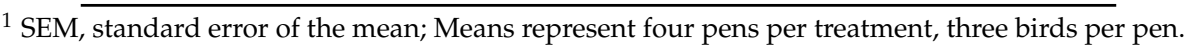


Table 4. Effects of test materials on blood metabolites in broilers (28 days).

\begin{tabular}{cccccc}
\hline Items & MDCP & MS & IS & SEM $^{\mathbf{1}}$ & $p$-Value \\
\hline Serum biochemicals & & & & & \\
\hline Aspartate aminotransferase (U/L) & 358.11 & 314.28 & 362.38 & 19.02 & 0.57 \\
Alanine Aminotransferase (U/L) & 1.93 & 1.91 & 1.79 & 0.12 & 0.90 \\
Blood urea nitrogen (mg/dL) & 1.28 & 1.21 & 1.13 & 0.06 & 0.60 \\
Creatinine (mg/dL) & 0.31 & 0.34 & 0.31 & 0.01 & 0.21 \\
Inorganic P (mg/dL) & 7.42 & 7.00 & 7.12 & 0.17 & 0.63 \\
Calcium (mg/dL) & $11.78^{\mathrm{b}}$ & $12.56^{\mathrm{a}}$ & $12.20^{\mathrm{a}, \mathrm{b}}$ & 0.13 & 0.03 \\
\hline Blood composition & & & & & \\
\hline Red blood cell (10 $/ \mu \mathrm{L})$ & 2.73 & 2.80 & 2.75 & 0.04 & 0.84 \\
White blood cells (10 $/ \mu \mathrm{LL})$ & 399.16 & 415.48 & 410.45 & 9.75 & 0.81 \\
Neutrophils $(\%)$ & 78.42 & 72.79 & 75.38 & 2.57 & 0.71 \\
Lymphocytes $(\%)$ & 0.00 & 0.00 & 0.00 & - & - \\
Eosinophils $(\%)$ & 0.00 & 0.00 & 0.00 & - & - \\
\hline
\end{tabular}

${ }^{1} \mathrm{SEM}$, standard error of the mean; ${ }^{\mathrm{a}, \mathrm{b}}$ Mean values within the same row with no common uppercase superscript indicate significant differences $(p<0.05)$; Means represent four pens per treatment, three birds per pen.

\section{Discussion}

Phosphate rock is the primary source of $\mathrm{P}$, and every year around $79 \%, 11 \%$, and $7 \%$ of the total phosphate rock mined worldwide has been used for producing fertilizers, feed additives, and detergents, respectively [26]. Due to the rise in the global population and rapid industrialization, the utilization of phosphate rock is increasing by $2 \%$ every year and the total $P$ reserves could be exhausted in the next 90-300 years [13,27]. Finding alternative sources of $P$ is therefore in demand.

Using typical coagulants like iron or aluminum salts for removing $\mathrm{P}$ from livestock wastewater produces sludges containing secondary contaminants $\left(\mathrm{FePO}_{4}, \mathrm{AlPO}_{4}\right)$ and therefore needs further treatment before disposal; thus, increasing the treatment cost. However, P recovered from swine wastewater as struvite precipitates requires no additional treatment. Considering the increasing demand and exhaustion of phosphate rock reserves, struvite recovery from wastewater appears to be more economical and sustainable on a large scale [8]. In this study, the recovered struvite was pre-treated as MS and IS to reduce the $\mathrm{NH}_{4}-\mathrm{N}$ concentration before using an alternative $\mathrm{P}$ source in broiler feed. MS showed major peaks indicative of struvite, while IS eliminated ammonium and hydrates from the struvite and decomposed as magnesium pyrophosphate. Between the two pre-treatment methods used in this study, microwave irradiation was more economically efficient than incineration. Past studies on cost analyses reported values of around USD 0.12/kg and 0.17/ $\mathrm{kg}$ for microwave irradiation and incineration pre-treatments, respectively $[28,29]$. However, further studies on detailed economic analysis with a preferred focus on recovery and pre-treatment cost, social costs reduction for environmental protection, and pollution prevention need to be conducted.

Until now, struvite has been extensively used as a fertilizer in agriculture. No studies have been reported on the explicit use of struvite recovered from livestock wastewater as a P source in animal diets yet, as there is a potential of contamination with toxic heavy metals or pathogens. A recent study showed that heavy metal contents in the struvite recovered from swine wastewater were lower than the Korean standard limits of fertilizer and feedstock guidelines suggested by the rural development administration of Korea [13]. Moreover, microwave irradiation can destroy the pathogens [30], while incineration usually is done to ensure the biological safety of infectious waste [31].

Dicalcium phosphate (DCP) is the most used dietary P source for broilers [32]. Therefore, in the present study, MDCP was used as a P source in control to study any difference in growth performance and blood metabolites of broilers fed with IS and MS. Weight gain is considered as a valuable criterion in P utilization studies. In this study, no significant difference in weight gain, feed intake, and FCR were observed in MS and IS treated groups compared to MDCP treated groups. 
Furthermore, the dietary struvite indicates no deleterious effects on relative organ weight, small intestine and tibia length, dry matter, crude ash, $\mathrm{Ca}$, and $\mathrm{P}$ level of the tibia. Moreover, dietary struvite increases the retention of digesta and results in higher ATTD of crude fat. As the retention time of digesta increases, it extends the enzymatic digestion time of dietary nutrients and ultimately improves the nutrient use efficiency $[33,34]$. The tibia and serum analysis results elucidated a normal level of $P$ utilization. Previous research showed that the source of $P$ supplement had a significant effect on the $\mathrm{Ca}$ and $\mathrm{P}$ contents of tibia and blood serum [35]. This difference may have resulted from the imbalance in the $\mathrm{Ca}$ to $\mathrm{P}$ ratio due to lower phosphate availability. In the present study, the Ca to P ratio in the broilers fed with MS, IS, and MDCP diets were constant at 2.2:1 and 2.4:1 in starter and finisher phases, respectively. The serum Ca and P concentrations in the broilers fed with test materials were well within the range of reference limits (Ca: 3.85 to $19.67 \mathrm{mg} / \mathrm{dL}$ and P: 3.48 to $19.49 \mathrm{mg} / \mathrm{dL}$ ) reported by Meluzzi et al. [36] and showed normal homeostatic regulation at the three primary target organs (the intestine, kidney, and bones) [37]. The Ca level in serum was found to be lower in MDCP than in MS fed groups, and equivalent to IS fed group. The difference in serum Ca concentration may be associated with the source of dietary $\mathrm{Ca}$ and possibly a higher absorption of $\mathrm{Ca}$ as limestone in MS treatment than Ca as di-calcium phosphate in control treatment. Apparent ileal digestibility of Ca has been shown to be affected by the Ca source and reported as $49 \%$ and $30 \%$ for limestone and di-calcium phosphate, respectively [38]. However, serum P level remained constant among the three treatment groups.

No differences in AST, ALT, BUN, CRE, and inorganic P were observed, whereas Ca level was found to be significantly higher in MS treated group compared to control. All these results belong to the normal range and imply no sign of infection or pathological condition. Serum levels of BUN, CRE, AST, and ALT were tested as a reflection of the metabolism and inner organ status of broilers. The AST and ALT levels are reported to be sensitive indicators of liver injury since an increase in these values reflects leakage from injured hepatocytes [39]. No significant change in the AST and ALT in IS and MS fed groups compared to control indicated normal liver functions. Similarly, no significant change in the BUN and CRE values confirmed that there were no deleterious effects on kidney functions in IS and MS fed broilers.

There were no significant differences in total and differential leukocyte (NEU, LYM, and EOS) counts in all the groups (control, MS, and IS). WBC or leukocytes play an important role in nonspecific or innate immunity and their counts can be considered as an indicator of the health status of broilers. LYM is an important leukocyte cell of the immune system that is involved in defending the body against both infectious diseases and external infectious microorganisms [40]. LYM count was found to be zero, while NEU counts were similar in all the groups. An excess number of leukocytes in the blood is often an indicator of disease or stress conditions. In stress conditions (due to infection, dietary imbalance, etc.), the leukocyte count increases [41]. In general, lower P availability or imbalance in the Ca to P ratio might be stressful to the broilers, which could lead to a change in leukocyte counts $[35,42,43]$.

In the present study, dietary treatments had no adverse effects on growth performance and blood metabolites, indicating the functional health status of broilers fed with pre-treated struvites. Considering chemical composition, nutrients contents, effectiveness, and the exhaustion of natural $P$ resources, struvite pre-treated as MS could be a potential alternative of commercial $P$ source in broiler feeds.

\section{Conclusions}

Given no significant differences in broilers' growth performance, higher crude fat and ash digestibility, no differences in organ weights and tibia composition, and no differences in blood parameters, the wastewater-recovered struvite can be used as an alternative P source in broiler feed. In addition, considering sustainability, resource recycling, reduction of social costs (environmental protection and pollution prevention, treatment costs, etc.), and depletion of phosphate rock reserves, the recovery of $\mathrm{P}$ from livestock wastewater and its utilization as feed additive might be a sustainable 
strategy. To our knowledge, this is the first study to evaluate the potential of using struvite in animal feed and also encourages further studies with more rigorous design to study the potential of struvite application in diverse fields.

Author Contributions: Conceptualization, S.W., B.J., J.K., and C.R.; methodology, S.W., B.J., J.K., and C.R.; software, A.R.; formal analysis, M.K., S.S., S.K., and S.A.; investigation, M.K., S.S., and S.K.; resources, C.R.; data curation, M.K., S.S., and A.R.; writing-original draft preparation, S.S., S.W., and A.R.; writing-review and editing, A.R., S.W., B.J., J.K., and C.R.; supervision, S.W. and C.R.; project administration, C.R.; funding acquisition, C.R.

Funding: This research was funded by the rural development administration of Korea, grant number PJ011623 and partially supported by the Kangwon National University.

Conflicts of Interest: The authors declare no conflict of interest. The funders had no role in the design of the study; in the collection, analyses, or interpretation of data; in the writing of the manuscript, or in the decision to publish the results.

\section{References}

1. Cordell, D.; Drangert, J.-O.; White, S. The Story of Phosphorus: Global food security and food for thought. Glob. Environ. Chang. 2009, 19, 292-305. [CrossRef]

2. Cordell, D.; White, S.; Drangert, J.-O.; Neset, T.S.S. Preferred future phosphorus scenarios: A framework for meeting long-term phosphorus needs for global food demand. In Proceedings of the International Conference on Nutrient Recovery from Wastewater Streams, Vancouver, BC, Canada, 10-13 May 2009; Ashley, K., Mavinic, D., Koch, F., Eds.; IWA Publishing: London, UK, 2009.

3. Cordell, D.; Rosemarin, A.; Schröder, J.J.; Smit, A.L. Towards global phosphorus security: A systems framework for phosphorus recovery and reuse options. Chemosphere 2011, 84, 747-758. [CrossRef] [PubMed]

4. Phosphorus Basics. Available online: https://crops.extension.iastate.edu/phosphorus-basics (accessed on 20 July 2019).

5. Reza, A.; Eum, J.; Jung, S.; Choi, Y.; Jang, C.; Kim, K.; Owen, J.S.; Kim, B. Phosphorus Budget for a Forested-Agricultural Watershed in Korea. Water 2019, 11, 4. [CrossRef]

6. Villamar, C.A.; Cañuta, T.; Belmonte, M.; Vidal, G. Characterization of Swine Wastewater by Toxicity Identification Evaluation Methodology (TIE). Water Air Soil Pollut. 2012, 223, 363-369. [CrossRef]

7. Desmidt, E.; Ghyselbrecht, K.; Zhang, Y.; Pinoy, L.; Van der Bruggen, B.; Verstraete, W.; Rabaey, K.; Meesschaert, B. Global phosphorus scarcity and full-scale P-recovery techniques: A review. Crit. Rev. Environ. Sci. Technol. 2015, 45, 336-384. [CrossRef]

8. Liu, Y.H.; Kumar, S.; Kwag, J.H.; Kim, J.H.; Kim, J.D.; Ra, C.S. Recycle of electrolytically dissolved struvite as an alternative to enhance phosphate and nitrogen recovery from swine wastewater. J. Hazard. Mater. 2011, 195, 175-181. [CrossRef]

9. Kazuyo, M.Y.; Hironari, K.; Kenichi, N.; Tetsuya, N. A material flow analysis of phosphorus in Japan. J. Ind. Ecol. 2009, 13, 687-705.

10. Symeou, V. Modelling the Phosphorous Intake, Digestion, Utilisation and Excretion in Growing and Finishing Pigs. Ph.D. Thesis, Newcastle University, Newcastle, UK, 2015.

11. Agudelo Trujillo, J.H.; Lindemann, M.D.; Cromwell, G.L. Phosphorus utilization in growing pigs fed a phosphorus deficient diet supplemented with a rice bran product and amended with phytase. Rev. Colomb. Cienc. Реcu. 2010, 23, 429-443.

12. Sharpley, A.; Moyer, B. Phosphorus forms in manure and compost and their release during simulated rainfall. J. Environ. Qual. 1999, 29, 1462-1469. [CrossRef]

13. Reza, A.; Shim, S.; Kim, S.; Ahmed, N.; Won, S.; Ra, C. Nutrient Leaching Loss of Pre-Treated Struvite and Its Application in Sudan Grass Cultivation as an Eco-Friendly and Sustainable Fertilizer Source. Sustainability 2019, 11, 4204. [CrossRef]

14. Ronteltap, M.; Maurer, M.; Gujer, W. The behaviour of pharmaceuticals and heavy metals during struvite precipitation in urine. Water Res. 2007, 41, 1859-1868. [CrossRef] [PubMed]

15. Ministry of Environment (MoE). Establishment and Operation of Centralized Livestock Wastewater Treatment Plant; Ministry of Environment: Sejong, Korea, 2018.

16. Rural Development Administration (RDA). Centralized Livestock Wastewater Treatment Plan 2019; Rural Development Administration: Jeonju, Korea, 2019. 
17. Ahmed, N.; Shim, S.; Won, S.; Ra, C. Struvite recovered from various types of wastewaters: Characteristics, soil leaching behaviour, and plant growth. Land Degrad. Dev. 2018, 29, 2864-2879. [CrossRef]

18. Yoon, T.H.; Won, S.G.; Lee, D.H.; Choi, J.W.; Ra, C.S.; Kim, J.D. Effect of a new phosphorus Source, magnesium hydrogen phosphate (MHP) on growth, utilization of phosphorus and physiological responses in Carp Cyprinus carpio. Fish Aquat. Sci. 2016, 19, 49-57. [CrossRef]

19. Li, B.; Boiarkina, I.; Yu, W.; Huang, H.M.; Munir, T.; Wang, G.Q.; Young, B.R. Phosphorus recovery through struvite crystallization: Challenges for future design. Sci. Total Environ. 2019, 648, 1244-1256. [CrossRef] [PubMed]

20. Husted, S.; Jensen, L.S.; Jørgensen, S.S. Reducing ammonia loss from cattle slurry by the use of acidifying additives: The role of the buffer system. J. Sci. Food Agric. 1991, 57, 335-349. [CrossRef]

21. Rahman, M.M.; Liu, Y.; Kwag, J.H.; Ra, C. Recovery of struvite from animal wastewater and its nutrient leaching loss in soil. J. Hazard. Mater. 2011, 186, 2026-2030. [CrossRef] [PubMed]

22. Skinner, J.T.; Waldroup, P.W. Allometric bone development in floor-reared broilers. J. Appl. Poult. Res. 1995, 4, 265-270. [CrossRef]

23. Najafi, P.; Torki, M. Performance, Blood Metabolites and Immunocompetaence of Broiler. J. Anim. Vet. Adv. 2010, 9, 1164-1168. [CrossRef]

24. AOAC. Official Methods of Analysis, 17th ed.; AOAC International: Rockville, MA, USA, 2005.

25. Blumenreich, S.M. The white blood cell and differential count. In Clinical Methods: The History, Physical and Laboratory Examination, 3rd ed.; Walker, H.M., Hall, W.D., Hurst, J.W., Eds.; Butterworth Publishers: Boston, MA, USA, 1990; pp. 724-727.

26. Liu, Y.; Kumar, S.; Kwag, J.H.; Ra, C. Magnesium ammonium phosphate formation, recovery and its application as valuable resources: A review. J. Chem. Technol. Biotechnol. 2013, 88, 181-189. [CrossRef]

27. Phosphate Rock Statistics and Information. Available online: https://www.usgs.gov/centers/nmic/phosphaterock-statistics-and-information (accessed on 25 July 2019).

28. Zimmermann, K. Microwave Technologies: An Emerging Tool for Inactivation of Biohazardous Material in Developing Countries. Recycling 2018, 3, 34. [CrossRef]

29. Kim, J.; Jeong, S. Economic and Environmental Cost Analysis of Incineration and Recovery Alternatives for Flammable Industrial Waste: The Case of South Korea. Sustainability 2017, 9, 1638. [CrossRef]

30. Janković, S.M.; Milošev, M.Z.; Novaković, M.L. The effects of microwave radiation on microbial cultures. Hosp. Pharmacol. 2014, 1, 102-108. [CrossRef]

31. Kanemitsu, K.; Inden, K.; Kunishima, H.; Ueno, K.; Hatta, M.; Gunji, Y.; Watanabe, I.; Kaku, M. Does incineration turn infectious waste aseptic? J. Hosp. Infect. 2005, 60, 304-306. [CrossRef] [PubMed]

32. Garcia, A.R.; Batal, A.B.; Dale, N.M. Biological availability of phosphorus sources in prestarter and starter diets for broiler chicks. J. Appl. Poult. Res. 2006, 15, 518-524. [CrossRef]

33. Kim, J.H.; Seo, S.; Kim, C.H.; Kim, J.W.; Lee, B.B.; Lee, G.I.; Shin, H.S.; Kim, M.C.; Kil, D.Y. Effect of dietary supplementation of crude glycerol or tallow on intestinal transit time and utilization of energy and nutrients in diets fed to broiler chickens. Livest. Sci. 2013, 154, 165-168. [CrossRef]

34. Kim, B.G.; Lindemann, M.D.; Cromwell, G.L.; Balfagon, A.; Agudelo, J.H. The correlation between passage rate of digesta and dry matter digestibility in various stages of swine. Livest. Sci. 2007, 109, 81-84. [CrossRef]

35. Tahir, M.; Lughmani, A.B.; Pesti, G.M. Evaluation of an indigenous source of rock phosphate as a supplement for broiler chickens. Poult. Sci. 2011, 90, 1983-1991. [CrossRef]

36. Meluzzi, A.; Primiceri, G.; Giordani, R.; Fabris, G. Determination of blood constituents reference values in broilers. Poult. Sci. 1992, 71, 337-345. [CrossRef]

37. Moe, S.M. Disorders Involving Calcium, Phosphorus, and Magnesium. Prim. Care 2008, 35, $215-237$. [CrossRef]

38. David, L.S.; Abdollahi, M.R.; Ravindran, G.; Walk, C.L.; Ravindran, V. Studies on the measurement of ileal calcium digestibility of calcium sources in broiler chickens. Poult. Sci. 2019, 98, 5582-5589. [CrossRef]

39. Nyblom, H.; Berggren, U.; Balldin, J.; Olsson, R. High AST/ALT ratio may indicate advanced alcoholic liver disease rather than heavy drinking. Alcohol Alcohol. 2004, 39, 336-339. [CrossRef] [PubMed]

40. Goel, A.; Bhanja, S.K.; Mehra, M.; Mandal, A.; Pande, V. In ovo trace element supplementation enhances expression of growth genes in embryo and immune genes in post-hatch broiler chickens. J. Sci. Food Agric. 2016, 96, 2737-2745. [CrossRef] [PubMed] 
41. Roberts, R.J.; Rodger, H.D. The pathophysiology and systemic pathology of teleosts. In Fish Pathology, 4th ed.; Roberts, R.J., Ed.; Bailliere Tindall: London, UK, 1978; pp. 55-91.

42. Li, J.; Yuan, J.; Guo, Y.; Sun, Q.; Hu, X. The influence of dietary calcium and phosphorus imbalance on intestinal NaPi-IIb and calbindin mRNA expression and tibia parameters of broilers. Asian Australas. J. Anim. Sci. 2012, 25, 552-558. [CrossRef] [PubMed]

43. Jordan, G.W. Serum calcium and phosphorus abnormalities in leukemia. Am. J. Med. 1966, 41, 381-390. [CrossRef]

(C) 2019 by the authors. Licensee MDPI, Basel, Switzerland. This article is an open access article distributed under the terms and conditions of the Creative Commons Attribution (CC BY) license (http://creativecommons.org/licenses/by/4.0/). 